\title{
Управление дисперсией одномодового волоконного световода при передаче мощных фемтосекундных импульсов
}

\author{
В. А. Бурдин ${ }^{1}$, А. В. Бурдин ${ }^{1}$ \\ ${ }^{I}$ Поволжский государственный университет телекоммуникаций и информатики \\ *E-mail: burdin@psati.ru
}

DOI:10.31868/RFL2018.146-147

С развитием техники и технологий лазеров ультракоротких импульсов и их приложений все более актуальной задачей становится анализ искажений оптических импульсов большой мощности при распространении в волоконных световодах. Как известно [1], в обычных кварцевых волокнах при энергии оптических импульсов менее 0,1 - 2 мкВт не следует ожидать необратимых изменений свойств материала. Соответственно, даже в таких оптических волокнах пиковая мощность фемтосекундных оптических импульсов единиц Мвт и более, не приводя к необратимым изменениям и, тем более, лазерному пробою. В работе [2] представлены результаты исследований профиля показателя преломления ступенчатого волоконного световода из плавленого кварцевого стекла с керровской нелинейностью при мощности оптического излучения в световоде до 0,2 МВт. Было показано, что даже при такой относительно небольшой мощности керровская нелинейность приводит к существенным изменениям дисперсионных характеристик. Очевидно, что с увеличением мощности, что возможно при передаче фемтосекундных импульсов, эти изменения будут более значительными. Здесь, на основе предложенного в [2] общего подхода были выполнены исследования дисперсионных характеристик кварцевого волоконного световода с керровской нелинейностью при пиковой мощности до 1,0 -10,0 МВт.

В [2], как и в большинстве работ при анализе передаточных характеристик световодов и процессов распространения в них оптических импульсов с учетом керровской нелинейности пренебрегали составляющей нелинейного показателя преломления второго порядка. В данной работе получены оценки обусловленных этим допущением погрешностей.

Изменения профиля показателя преломления кварцевых ступенчатых волоконных световодов за счет керровской нелинейности определяли, как было предложено в [2-4]. Для анализа дисперсионных характеристик воспользовались аналитическими выражениями, полученными в [4], где методом приближения Гаусса было найдено характеристическое уравнение относительно эквивалентного радиуса пятна фундаментальной моды и для этой моды выведены аналитические формулы для постоянной распространения и ее первой, второй и третьей производных, а также для времени задержки и хроматической дисперсии первого и второго порядков (параметра хроматической дисперсии и наклона дисперсионной характеристики). По указанным формулам были получены зависимости параметров хроматической дисперсии от пиковой мощности оптического излучения в световоде, которые наглядно демонстрируют возможности управления дисперсионными характеристиками за счет выбора пиковой мощности оптических импульсов. Также, были рассмотрены возможности управления дисперсионными характеристиками волоконного световода за счет выбора его профиля показателя преломления. Получены оценки погрешностей расчета параметров хроматической дисперсии за счет отбрасывания составляющей нелинейного показателя преломления второго порядка. В качестве 
примера на рис.1 приведены зависимости параметра хроматической дисперсии моды $L P_{01}$ от пиковой мощности оптического излучения в световоде для кварцевого ступенчатого оптического волокна с керровской нелинейностью с диаметром сердцевины 1,3 мкм и числовой апертурой 0,12 на длине волны 800 нм. На рис. 2 для этого примера представлен график зависимости от пиковой мощности погрешности оценок параметра хроматической дисперсии, обусловленной отбрасыванием составляющей нелинейного показателя преломления второго порядка. Как следует из полученных результатов анализ дисперсионных характеристик требует учета всех составляющих нелинейного показателя преломления материалов световода. Это подтверждает и разница между результатами моделирования распространения оптических импульсов большой мощности в оптическом волокне, полученными с учетом всех составляющих и при исключении составляющей второго порядка.

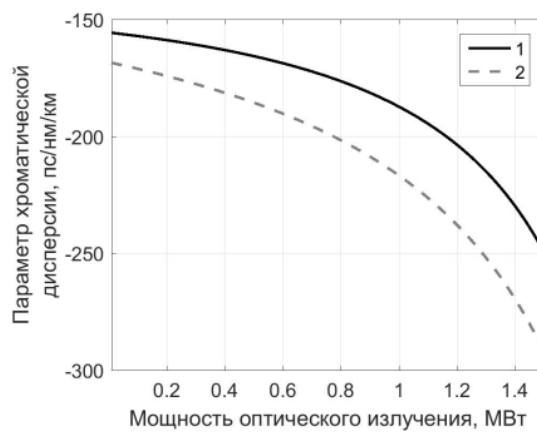

Рис.1

$$
\text { Зависимость }
$$

параметра ступенчатого волоконного световода с керровской нелинейностью от мощности оптического излучения, 1 - с учетом всех составляющих нелинейного показателя преломления материала, 2 - учет только одной составляющей.

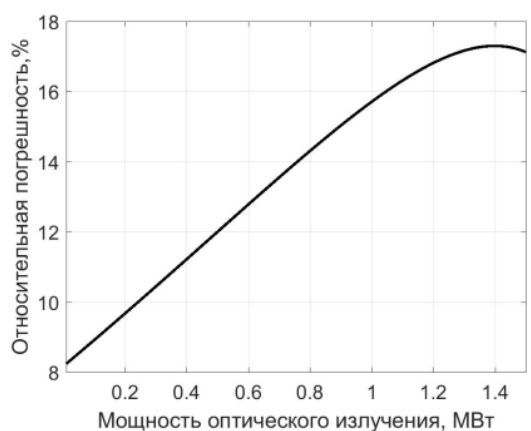

Рис.2 Зависимость от мощности оптического излучения относительной погрешности вычисления параметра хроматической дисперсии, обусловленной пренебрежением одной из составляющих нелинейного показателя преломления материала

Полученные в представленной работе результаты подтверждают возможности управления дисперсионными характеристиками волоконного световода за счет выбора пиковой мощности оптического излучения и выбора профиля показателя преломления световода. При этом показано, что анализ дисперсионных характеристик световода требует учета всех составляющих нелинейного показателя преломления материалов.

\section{Литература}

[1] B. Poumellec, M. Lancry et al, Optical Materials Exspress 1(4), 766-782 (2011)

[2] K. Okamoto, E.A.J. Marcatili, J. Lightwave Technology 1(12), 1988-1994 (1989)

[3] V.A. Burdin, A.V. Burdin et al, Optics and Spectroscopy 123(2), 193-199 (2017)

[4] В.А. Бурдин, А.В. Бурдин и др., Физика волн. процессов и радиотехнические системы 20(3/2), 47-51 (2017) 